\title{
Spectrophotometric Determination of Iodine Species in Table Salt and Pharmaceutical Preparations
}

\author{
George Mary, ${ }^{a}$ Natesan Balasubramanian, ${ }^{b}$ and Karachalacherevu Seetharamiah NAGARAJA ${ }^{*}, a$ \\ ${ }^{a}$ Department of Chemistry, Loyola Institute of Frontier Energy (LIFE), Loyola College; Chennai 600 034, India: and \\ ${ }^{b}$ Department of Chemistry, Indian Institute of Technology; Madras Chennai 600 036, India. \\ Received November 21, 2007; accepted March 30, 2008; published online April 14, 2008
}

\begin{abstract}
A sensitive spectrophotometric method for the determination of iodine species like iodide, iodine, iodate and periodate is described. The method involves the oxidation of iodide to $\mathrm{ICl}_{2}^{-}$in the presence of iodate and chloride in acidic medium. The formed $\mathrm{ICl}_{2}^{-}$bleaches the dye methyl red. The decrease in the intensity of the colour of the dye is measured at $520 \mathrm{~nm}$. Beer's law is obeyed in the concentration range $0-3.5 \mu \mathrm{g}$ of iodide in an overall volume of $10 \mathrm{ml}$. The molar absorptivity of the colour system is $1.73 \times 10^{5} \mathrm{I} \mathrm{mol}^{-1} \mathrm{~cm}^{-1}$ with a correlation coefficient of -0.9997 . The relative standard deviation is $3.6 \%(n=10)$ at $2 \mu \mathrm{g}$ of iodide. The developed method can be applied to samples containing iodine, iodate and periodate by prereduction to iodide using $\mathrm{Zn} / \mathrm{H}^{+}$or $\mathrm{NH}_{2} \mathrm{NH}_{2} / \mathrm{H}^{+}$. The effect of interfering ions on the determination is described. The proposed method has been successfully applied for the determination of iodide and iodate in salt samples and iodine in pharmaceutical preparations.
\end{abstract}

Key words spectrophotometry; iodine species; $\mathrm{ICl}_{2}^{-}$; methyl red

Iodine is an essential micronutrient in human growth and is very important for iodine supplementation metabolism. Deficiency of iodine causes serious delay in neurological development, goiter and hypothyroidism. ${ }^{1}$ Table salts are iodized with iodate or iodide to serve as a source of iodine. The iodized salt is recognized as the method of choice and the most successful strategy for the prevention of iodine deficiency disorders. The recommended concentration of iodate in salts is $40 \mathrm{ppm}^{2)}$ Iodine is an effective germicide for a wide range of microorganisms. Iodine is often used in conjunction with complexing nonionic surfactants or polymers (iodophors) in disinfectants that are used in dairies, laboratories and food processing plants. In addition to this iodine finds applications as dietary supplements, catalysts, pharmaceutical preparations, stabilizers and in photography. Iodine is also used in the production of motor fuels, high purity metals and in cloud seeding. The varied applications of iodine have made the determination of iodine very important.

Several methods of iodine determination have been proposed, including selective electrodes, ${ }^{3)}$ X-ray fluorescence $(\mathrm{XRF}){ }^{4)}$ inductively coupled plasma mass spectrometry (ICP-MS). ${ }^{5,6)}$ Trace levels of iodide have been determined by the catalytic effect usually on the cerium(IV)-arsenic(III) reaction. ${ }^{7,8)}$ Other reactions catalyzed or inhibited by iodide have also been described. ${ }^{9,10)}$ Precipitation as silver iodide, dissolution in potassium cyanide, and determination of silver in the complex by atomic absorption spectrometry has been used for the indirect determination of iodide in a flow system. ${ }^{11)}$ Sensitive extraction photometric methods based on ion-pair formation with methylene blue, ${ }^{12)}$ or with brilliant green $^{13)}$ are well known. Recently methods based on the oxidation of leuco xylene cyanol $\mathrm{FF}^{14)}$ or thionin ${ }^{15)}$ with iodate are reported. Several spectrophotometric methods have been reported for the determination of periodate and iodate. ${ }^{16-20)}$ El-Shahawi ${ }^{21)}$ used the ion-associate of periodate with amiloride hydrochloride for simultaneous spectrophotometric determination of periodate and iodate by liquid-liquid extraction. Most of the reported methods are not sensitive enough or require complicated and expensive instruments.
There is a need for the determination of iodine species in table salts and pharmaceutical samples. The developed method should be sensitive, simple and reliable.

This paper describes a spectrophotometric method for the determination of iodine species like iodide, iodine, iodate and periodate. The method involves the oxidation of iodide to $\mathrm{ICl}_{2}^{-}$in the presence of iodate and chloride in acidic medium. ${ }^{22}$ The formed $\mathrm{ICl}_{2}^{-}$bleaches the dye methyl red. The decrease in the intensity of the colour of the dye is measured at $520 \mathrm{~nm}$. The system obeys Beer's law in the concentration range $0-3.5 \mu \mathrm{g}$ of iodide in an overall volume of $10 \mathrm{ml}$. The developed method can be applied directly to samples containing iodide and iodine and after prereduction of iodate and periodate to iodide using $\mathrm{Zn} / \mathrm{H}^{+}$or $\mathrm{NH}_{2} \mathrm{NH}_{2} / \mathrm{H}^{+}$. The proposed method has been successfully applied to the determination of iodide and iodate in salt samples and iodine in pharmaceutical preparations.

\section{Experimental}

Apparatus All absorbance measurements were made using Elico SL 177 scanning spectrophotometer with $1 \mathrm{~cm}$ glass cells.

Reagents All reagents were of analytical reagent grade and distilled water was used for preparing all solutions.

A stock solution of iodide $(1000 \mathrm{ppm})$ was prepared by dissolving $0.1307 \mathrm{~g}$ of potassium iodide in distilled water and made upto $100 \mathrm{ml}$ in a standard flask. A working solution of $1 \mu \mathrm{g} \mathrm{ml}^{-1}$ was prepared by suitable dilution. A stock solution of iodate $(1000 \mathrm{ppm})$ was prepared by dissolving $0.1223 \mathrm{~g}$ of potassium iodate in distilled water and made upto $100 \mathrm{ml}$ in a standard flask. A working solution of $69 \mu \mathrm{g} \mathrm{ml}^{-1}$ was prepared by suitable dilution. A stock solution of periodate $(1000 \mathrm{ppm})$ was prepared by dissolving $0.1205 \mathrm{~g}$ of potassium periodate in distilled water and made upto $100 \mathrm{ml}$ in a standard flask. A working solution of $75 \mu \mathrm{g} \mathrm{ml}^{-1}$ was prepared on dilution. Iodate solution $(0.04 \%)$ was prepared by dissolving $0.040 \mathrm{~g}$ of potassium iodate in $100 \mathrm{ml}$ of distilled water. Sodium chloride solution $(22 \%)$ was prepared by dissolving $22 \mathrm{~g}$ of sodium chloride in $100 \mathrm{ml}$ of distilled water. Sulphuric acid $(6 \mathrm{M})$ was prepared by the addition of $166.7 \mathrm{ml}$ of concentrated sulphuric acid (Sp. Gravity 1.84) to $200 \mathrm{ml}$ of distilled water, cooled and diluted to $500 \mathrm{ml}$. Methyl red solution $(0.003 \%)$ was prepared by dissolving $0.1 \mathrm{~g}$ of methyl red dye in $1 \mathrm{ml}$ of $4.5 \mathrm{~N}$ sodium hydroxide and diluting to $100 \mathrm{ml}$. Ten milliliters of this solution was diluted to $100 \mathrm{ml}$ after acidifying it by adding $0.5 \mathrm{ml}$ of $6 \mathrm{M}$ sulphuric acid. Thirty milliliters of this solution was diluted to $100 \mathrm{ml}$ to obtain $0.003 \%$ methyl red. Hydrazine solution $(400 \mathrm{ppm})$ was prepared by dissolving $0.1626 \mathrm{~g}$ of hydrazinium sulphate 
in $100 \mathrm{ml}$ of water. Formaldehyde solution $(7600 \mathrm{ppm})$ was prepared by diluting $2 \mathrm{ml}$ of formaldehyde (38\%) to $100 \mathrm{ml}$ with water. Suitable aliquot of this solution was diluted to obtain $1000 \mathrm{ppm}$ solution. $p$-Phenylenediamine solution $(0.5 \%)$ was prepared by dissolving $0.50 \mathrm{~g}$ of $p$-phenylenediamine in $5 \mathrm{ml}$ of $6 \mathrm{M}$ sulphuric acid and diluting to $100 \mathrm{ml}$ with distilled water. Bromine solution $(600 \mathrm{ppm})$ was prepared by dissolving $0.2143 \mathrm{~g}$ of potassium bromate and $2.143 \mathrm{~g}$ of potassium bromide and diluting to 11 with water. Fifty milliliters of this stock solution was transferred into a $100 \mathrm{ml}$ calibrated flask containing $40 \mathrm{ml}$ of $4.25 \mathrm{M}$ sulphuric acid and diluting to $100 \mathrm{ml}$ with water $(300 \mathrm{ppm})$. This solution was prepared on the day of use. Sulphuric acid $(4.25 \mathrm{M})$ was prepared by adding $59 \mathrm{ml}$ of concentrated sulphuric acid (Sp. Gravity 1.84) to $150 \mathrm{ml}$ of water, cooled and then diluting to $250 \mathrm{ml}$. Sulphamic acid solution $(1000 \mathrm{ppm})$ was prepared by dissolving $0.1 \mathrm{~g}$ of sulphamic acid in $100 \mathrm{ml}$ of water.

Procedure. Calibration Graph To a series of $10 \mathrm{ml}$ calibrated flasks, $3 \mathrm{ml}$ aliquot of the sample containing $0-3.5 \mu \mathrm{g}$ of iodide, $2 \mathrm{ml}$ of $0.04 \%$ iodate, $1 \mathrm{ml}$ of $22 \%$ sodium chloride and $1 \mathrm{ml}$ of $6 \mathrm{M}$ sulphuric acid were added. The solutions were mixed well and kept aside for $10 \mathrm{~min}$. One milliliter of $0.003 \%$ methyl red was added before diluting to $10 \mathrm{ml}$ with distilled water. The absorbance of the solution was measured at $520 \mathrm{~nm}$ against water The plot of absorbance versus concentration of iodine is a straight line with negative slope.

Determination of Iodide in Salt Samples Dissolve 5-10g of salt sample in $70-80 \mathrm{ml}$ of water taken in a beaker. Filter the sample and dilute it to $100 \mathrm{ml}$ in a calibrated flask. Dilute the sample suitably to get a solution containing $1 \mu \mathrm{g} \mathrm{ml}^{-1}$ of iodide. Three milliliters of the sample containing not more than $3.5 \mu \mathrm{g}$ of iodide is treated with $2 \mathrm{ml}$ of $0.04 \%$ iodate, $1 \mathrm{ml}$ of $22 \%$ sodium chloride and $1 \mathrm{ml}$ of $6 \mathrm{~m}$ sulphuric acid. The solutions were mixed well and kept aside for $10 \mathrm{~min}$. One milliliter of $0.003 \%$ methyl red was added before diluting to $10 \mathrm{ml}$ with distilled water in a calibrated flask. The absorbance of the solution was measured at $520 \mathrm{~nm}$ against water. The concentration of iodide is established from the calibration graph.

Determination of Iodate and Periodate Method 1: Reduction of Iodate and Periodate to Iodide Using $\mathrm{Zn} / \mathrm{H}^{+}$: One milliliter of $69 \mu \mathrm{g} \mathrm{ml}^{-1}$ of iodate or $75 \mu \mathrm{g} \mathrm{ml}^{-1}$ of periodate is added to $25 \mathrm{ml}$ of water taken in a $50 \mathrm{ml}$ beaker. To this $0.2-0.25 \mathrm{~g}$ of zinc metal and $1 \mathrm{ml}$ of $6 \mathrm{~m}$ sulphuric acid were added and the contents were mixed well and kept aside till the dissolution of zinc. The solution was made upto $50 \mathrm{ml}$. Each milliliter is equivalent to $1 \mu \mathrm{g}$ of iodide (Chart 1).

Determination of Iodate in Salt Samples Twenty to twenty-five grams of salt samples containing iodate were dissolved in $70-80 \mathrm{ml}$ water taken in a beaker. Filter the sample and dilute the sample to $100 \mathrm{ml}$ in a calibrated flask. Ten milliliters of the salt solution is added to $15 \mathrm{ml}$ of water taken in a $50 \mathrm{ml}$ beaker. To this $0.2-0.25 \mathrm{~g}$ of zinc metal and $1 \mathrm{ml}$ of $6 \mathrm{M}$ sulphuric acid were added and the contents were mixed and kept aside for dissolution of zinc. The solution was made upto $50 \mathrm{ml}$. To $3 \mathrm{ml}$ of this solution, $2 \mathrm{ml}$ of $0.04 \%$ iodate, $1 \mathrm{ml}$ of $22 \%$ sodium chloride and $1 \mathrm{ml}$ of $6 \mathrm{M}$ sulphuric acid were added. The contents were mixed well and kept aside for $10 \mathrm{~min}$. One milliliter of $0.003 \%$ methyl red was added before diluting to $10 \mathrm{ml}$ with distilled water in a calibrated flask. The absorbance of the solution was measured at $520 \mathrm{~nm}$ against distilled water. The concentration of iodide is established from the calibration graph. Concentration of iodate is calculated.

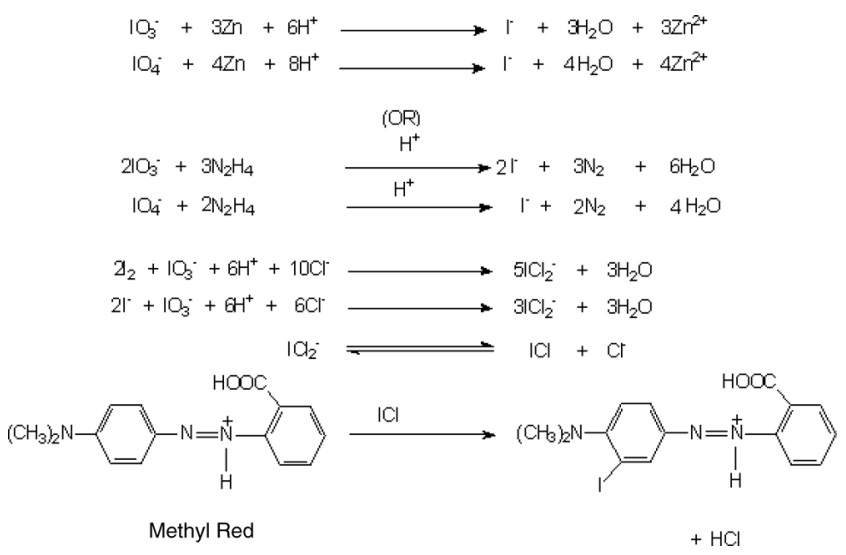

Chart 1. Reaction Scheme concentration of iodate in $50 \mathrm{ml}=$ concentration of iodide $\times 1.378 \times 50 / 3$ concentration of periodate in $50 \mathrm{ml}=$ concentration of iodide $\times 1.5 \times 50 / 3$

Method 2: Reduction of Iodate and Periodate to Iodide Using Hydrazine and Acid: One milliliter of $69 \mu \mathrm{g} \mathrm{ml}^{-1}$ of iodate or $75 \mu \mathrm{g} \mathrm{ml}^{-1}$ of periodate is added to $25 \mathrm{ml}$ of water taken in a 50 calibrated flask. To this $1 \mathrm{ml}$ of $400 \mathrm{ppm}$ hydrazine and $1 \mathrm{ml}$ of $6 \mathrm{M}$ sulphuric acid were added and the contents were mixed well and kept aside for $10 \mathrm{~min}$. One milliliter of $1000 \mathrm{ppm}$ formaldehyde was added mixed well and diluted to $50 \mathrm{ml}$. Each milliliter is equivalent to $1 \mu \mathrm{g}$ of iodide (Chart 1).

Determination of Iodate in Salt Samples Twenty to twenty-five grams of salt samples containing iodate were dissolved in $70-80 \mathrm{ml}$ water taken in a beaker. Filter the sample and dilute the sample to $100 \mathrm{ml}$ in a calibrated flask. Ten milliliters of the salt solution is added to $15 \mathrm{ml}$ of water taken in a $50 \mathrm{ml}$ calibrated flask. To this $1 \mathrm{ml}$ of $400 \mathrm{ppm}$ hydrazine and $1 \mathrm{ml}$ of $6 \mathrm{M} \mathrm{sul}-$ phuric acid were added and the contents were mixed well and kept aside for $10 \mathrm{~min}$. One milliliter of $1000 \mathrm{ppm}$ formaldehyde was added mixed well and diluted to $50 \mathrm{ml}$. To $3 \mathrm{ml}$ of this solution, $2 \mathrm{ml}$ of $0.04 \%$ iodate, $1 \mathrm{ml}$ of $22 \%$ sodium chloride and $1 \mathrm{ml}$ of $6 \mathrm{~m}$ sulphuric acid were added. The contents were mixed well and kept aside for $10 \mathrm{~min}$. One milliliter of $0.003 \%$ methyl red was added before diluting to $10 \mathrm{ml}$ with distilled water in a calibrated flask. The absorbance of the solution was measured at $520 \mathrm{~nm}$ against distilled water. The concentration of iodide is established from the calibration graph. The concentration of iodate is calculated.

concentration of iodate in $50 \mathrm{ml}=$ concentration of iodide $\times 1.378 \times 50 / 3$ concentration of periodate in $50 \mathrm{ml}=$ concentration of iodide $\times 1.5 \times 50 / 3$

Determination of Iodine in Pharmaceutical Samples Dissolve $0.5 \mathrm{~g}$ of iodine containing ointment or dilute $1 \mathrm{ml}$ of iodine containing pharmaceutical preparation to $50 \mathrm{ml}$. Take $1 \mathrm{ml}$ of the diluted solution and further dilute it to $50 \mathrm{ml}$ in a calibrated flask. Take $3 \mathrm{ml}$ of sample containing not more than $3.5 \mu \mathrm{g}$ of iodine and analyse it following the procedure recommended under calibration graph. Calculate the concentration of iodine in the sample.

Following the above recommended procedures, analysis of 5 samples containing iodine species can be completed in $60 \mathrm{~min}$.

\section{Results and Discussion}

Quantitative bleaching of azo dyes by halogens like chlorine or bromine is widely used for their spectrophotometric determinations. ${ }^{23)}$ The present method involves the oxidation of iodide to $\mathrm{ICl}$ and stabilization as $\mathrm{ICl}_{2}^{-}\left(\mathrm{ICl}+\mathrm{Cl}^{-} \rightleftarrows \mathrm{ICl}_{2}^{-}\right)$in the presence of iodate and chloride in acid medium. The formed $\mathrm{ICl}_{2}^{-}$bleaches the dye methyl red and the decrease in the intensity of the colour is a measure of iodide concentration.

Methyl red, an azodye, shows two absorption bands at $520 \mathrm{~nm}$ and $315 \mathrm{~nm}$. The intensity of the band at $315 \mathrm{~nm}$ is very weak compared with the band at $520 \mathrm{~nm}$ (Fig. 1).

It was observed that with increasing $\mathrm{ICl}_{2}^{-}$concentration, absorption decreases for the band at $520 \mathrm{~nm}$ whereas it in-

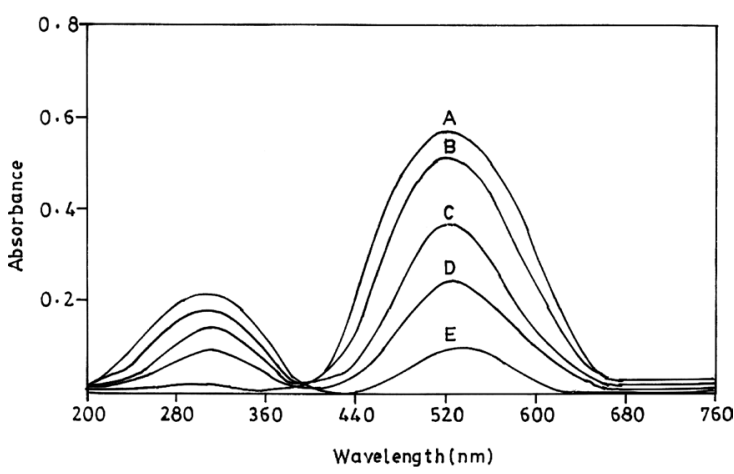

Fig. 1. Absorption Spectra of Methyl Red Measured against Water A, blank; B, $0.5 \mu \mathrm{g}$ of iodide; C, $1.5 \mu \mathrm{g}$ of iodide; D, $2.5 \mu \mathrm{g}$ of iodide; $\mathrm{E}, 3.5 \mu \mathrm{g}$ of iodide. 
creased for the band at $315 \mathrm{~nm}$ (Fig. 1). The reaction of $\mathrm{ICl}_{2}^{-}$ with methyl red involves competition between aromatic ring substitution and azo link cleavage resulting in the bleaching of colour at $520 \mathrm{~nm}$. The bleaching of the colour of methyl red by strong oxidizing agents like $\mathrm{MnO}_{4}^{-}, \mathrm{Ce}^{4+}$ and $\mathrm{Cr}_{2} \mathrm{O}_{7}^{2-}$ is by oxidative destruction of azo linkage. The proposed scheme of bleaching of methyl red by $\mathrm{ICl}$ is similar to the bleaching of colour of methyl orange by chlorine or bromine. $^{23)}$ In the case of chlorine (stronger oxidizing agent compared to bromine) the bleaching is carried upto $70 \%$ by oxidation of azo linkage and $30 \%$ by aromatic ring substitution.

In the case of bromine the bleaching of methyl orange is greater than $95 \%$ by aromatic ring substitution. This was clearly established by the synthesis and spectral characterization of relevant compounds. ${ }^{23)} \mathrm{ICl}$ is a good iodinating agent compared to iodine. ${ }^{24)}$ Iodination of dyes like dichlorofluorescein and thymol blue with ICl were used for the spectrophotometric determination of ascorbic acid ${ }^{25)}$ and sulphur dioxide. ${ }^{26}$ Based on this, the major pathway of bleaching of methyl red by $\mathrm{ICl}$ is by aromatic ring substitution by iodine (Chart 1). The system obeys Beer's law in the concentration range of $0-3.5 \mu \mathrm{g}$ of iodide in an overall volume of $10 \mathrm{ml}$.

Experimental conditions were optimized for the formation of ICl using $2 \mu \mathrm{g}$ of iodide. The effect of variation of iodate was studied. It was established that a minimum of $1 \mathrm{ml}$ of $0.04 \%$ iodate was required for the formation of ICl. Further addition upto $1 \mathrm{ml}$ of $0.12 \%$ of iodate showed no change in the formation of $\mathrm{ICl}$ for a given concentration of iodide. Hence $2 \mathrm{ml}$ of $0.04 \%$ is recommended as optimum concentration.

The amount of chloride required for the reaction was studied. It was found that a minimum of $1 \mathrm{ml}$ of $15 \%$ sodium chloride is sufficient for the formation of $\mathrm{ICl}$ and stabilization as $\mathrm{ICl}_{2}^{-}$. Addition upto $1 \mathrm{ml}$ of $30 \%$ sodium chloride showed no change in the formation of $\mathrm{ICl}$ with $2 \mu \mathrm{g}$ of iodide. Hence the use of $1 \mathrm{ml}$ of $22 \%$ sodium chloride is recommended.

The effect of variation of acidity required for the reaction was studied. It was established that a minimum of $1 \mathrm{ml}$ of $4 \mathrm{M}$ sulphuric acid is sufficient for the formation of $\mathrm{ICl}$ and its stabilization as $\mathrm{ICl}_{2}^{-}$. Further addition upto $1 \mathrm{ml}$ of $7 \mathrm{M}$ sulphuric acid showed no change in the formation of ICl. Hence $1 \mathrm{ml}$ of $6 \mathrm{M}$ sulphuric acid is recommended as the optimum concentration of sulphuric acid.

The effect of methyl red concentration required for bleaching by $\mathrm{ICl}_{2}^{-}$was studied. One milliliter of $0.003 \%$ methyl red solution is recommended as optimum concentration to have maximum absorbance at $520 \mathrm{~nm}$ in an overall volume of $10 \mathrm{ml}$.

Samples containing iodate or periodate require reduction to iodide in acidic medium prior to determination. This was achieved by using zinc and acid or with hydrazine solution. The unreacted hydrazine should be removed prior to the conversion of iodide to $\mathrm{ICl}$ with iodate. The effect of excess hydrazine was masked by the addition of $1 \mathrm{ml}$ of $1000 \mathrm{ppm}$ formaldehyde solution. Reduction of iodate or periodate to iodide by both methods gave excellent results. Samples containing iodine can be directly used for its determination like iodide without the reduction step.

Under these conditions the system obeys Beer's law in the
Table 1. Effect of Some Interfering Species in the Iodide Determination (Iodide $=2 \mu \mathrm{g})$

\begin{tabular}{|c|c|}
\hline Species & Amount tolerated $(\mu \mathrm{g})$ \\
\hline $\begin{array}{l}\text { Phosphate, oxalate, citrate, } \\
\text { tartrate, borate, carbonate, bicarbonate, } \\
\text { fluoride, oxalate, sulphate }\end{array}$ & 1000 \\
\hline $\mathrm{Br}^{-}$ & 2 \\
\hline $\begin{array}{l}\mathrm{Ba}(\mathrm{II}), \mathrm{Pb}(\mathrm{II}), \mathrm{Mg}(\mathrm{II}), \mathrm{Co}(\mathrm{II}), \\
\quad \mathrm{Cd}(\mathrm{II}), \mathrm{Bi}(\mathrm{III}), \mathrm{Ni}(\mathrm{II}), \mathrm{Li}(\mathrm{I}), \mathrm{Mn}(\mathrm{II}), \\
\quad \mathrm{Sr}(\mathrm{II}), \mathrm{Cr}(\mathrm{III}), \mathrm{NH}_{4}^{+}\end{array}$ & 1000 \\
\hline $\mathrm{NO}_{3}^{-}$ & 100 \\
\hline $\mathrm{NO}_{2}^{-}$ & 10 \\
\hline $\mathrm{NO}_{2}^{-a}$ & 100 \\
\hline Sulphamic acid & 1000 \\
\hline $\mathrm{SO}_{3}^{2-}, \mathrm{S}_{2} \mathrm{O}_{3}^{2-}$ & 1 \\
\hline Hydrazine & 1 \\
\hline Hydroxylamine & 1 \\
\hline Hydrazine $^{b)}$ & 400 \\
\hline Hydroxylamine $^{b)}$ & 400 \\
\hline $\mathrm{HCHO}$ & 1000 \\
\hline $\mathrm{Fe}(\mathrm{II})$ & 10 \\
\hline $\mathrm{Fe}(\mathrm{III})$ & 2 \\
\hline $\mathrm{Hg}(\mathrm{II}), \mathrm{Cu}(\mathrm{II})$ & 5 \\
\hline Glucose, acetone & 100 \\
\hline
\end{tabular}

a) Treated with $1 \mathrm{ml}$ of $1000 \mathrm{ppm}$ sulphamic acid solution prior to the addition of iodate to form $\mathrm{ICl}_{2}^{-}$. b) Treated with $1 \mathrm{ml}$ of $1000 \mathrm{ppm} \mathrm{HCHO}$ solution prior to the addition of iodate to form $\mathrm{ICl}_{2}^{-}$.

concentration range $0-3.5 \mu \mathrm{g}$ of iodide. The detection limit of iodide $(3 \sigma)$ is $0.22 \mu \mathrm{g}$ in an overall volume of $10 \mathrm{ml}$. The molar absorptivity of the system was found to be $1.73 \times$ $10^{5} 1 \mathrm{~mol}^{-1} \mathrm{~cm}^{-1}$. A calibration graph was obtained with a negative slope and the equation being $Y=-0.1342 X+0.5718$ where $Y$ is the absorbance and $X(\mu \mathrm{g})$ is the concentration of iodide. The correlation coefficient was -0.9997 and the relative standard deviation was $3.6 \%(n=10)$ for $2 \mu \mathrm{g}$ of iodide.

Interferences The interfering effect of anions and cations, which may co-exist with iodide were studied. Any deviation in the absorbance value of \pm 0.01 to that obtained in the absence of other interfering ions in iodide determination was taken as a sign of interference. Varying concentration of interfering species were introduced along with $2 \mu \mathrm{g}$ of iodide and the absorbance values were compared to that in the absence of interference. Tolerance limit of various ions studied in iodide determination are summarized in Table 1.

Hydrazine and hydroxylamine were tolerated upto $400 \mathrm{ppm}$ by the addition of $1000 \mathrm{ppm} \mathrm{HCHO}$ prior to the addition of iodate to form $\mathrm{ICl}_{2}^{-}$. Nitrite was tolerated upto $100 \mathrm{ppm}$ by treating with $1 \mathrm{ml}$ of $1000 \mathrm{ppm}$ sulphamic acid prior to the addition of iodate to form $\mathrm{ICl}_{2}^{-}$.

Applications In order to evaluate the analytical applicability of the proposed method sample of table salts containing iodide or iodate and pharmaceutical preparations containing iodine were analysed. The salt samples from the local market, U.S.A., U.K. and Germany were analyzed. $p$ Phenylenediamine method $^{2}$ was used as reference method to compare results. The method is based on the oxidation of $p$ phenylenediamine with iodate in acid medium. Tables 2 and 2A show the results obtained for the analysis of iodate in iodized salt from India and Germany by both the proposed and reference method. ${ }^{2)}$ In the reference method, a $10 \mathrm{ml}$ aliquot of sodium chloride solution $(25 \%), 0-5 \mathrm{ml}$ of $80 \mathrm{ppm}$ iodate, $4 \mathrm{ml}$ of $0.5 \% \mathrm{p}$-phenylenediamine (ppda) in 
Table 2. Determination of Iodate in Iodized Salt

\begin{tabular}{|c|c|c|c|c|c|}
\hline \multirow[t]{2}{*}{ Salt sample (Manufacturer) } & \multirow[t]{2}{*}{ Manufacturer's claim } & \multicolumn{2}{|c|}{$\begin{array}{l}\text { Amount of iodate } \\
\text { present }(\mathrm{ppm}) \\
\text { Developed method }{ }^{a)}\end{array}$} & \multirow{2}{*}{$\begin{array}{c}\text { Amount of iodate } \\
\text { present (ppm) } \\
p \text {-Phenylene } \\
\text { diamine } \\
\text { method }^{b)}\end{array}$} & \multirow{2}{*}{$\begin{array}{l}\text { Amount of iodate } \\
\text { present (ppm) } \\
\text { BIS method }{ }^{c}\end{array}$} \\
\hline & & $\mathrm{Zn} / \mathrm{H}^{+}$ & $\mathrm{NH}_{2} \mathrm{NH}_{2} / \mathrm{H}^{+}$ & & \\
\hline \multirow{4}{*}{$\begin{array}{l}\text { Annapurna (Hindustan Lever Ltd., } \\
\text { Mumbai, India) }\end{array}$} & Minimum $30 \mathrm{ppm}$ of iodine & 41.34 & 39.62 & 38.40 & 39.66 \\
\hline & $\equiv$ iodate $41.34 \mathrm{ppm}$ & 39.62 & 39.62 & 41.60 & 39.13 \\
\hline & & 38.47 & 39.04 & 40.00 & 40.19 \\
\hline & & $39.81^{d)}$ & $39.43^{d)}$ & $40.00^{d)}$ & $39.66^{d)}$ \\
\hline Aashirvaad (ITC Ltd., & Minimum $30 \mathrm{ppm}$ of iodine & 37.34 & 39.62 & 41.60 & 40.72 \\
\hline \multirow{3}{*}{ Kolkata, India) } & $\equiv$ iodate $41.34 \mathrm{ppm}$ & 41.34 & 42.20 & 41.60 & 40.72 \\
\hline & & 41.34 & 40.19 & 40.00 & 39.66 \\
\hline & & $40.01^{d)}$ & $40.67^{d)}$ & $41.07^{d)}$ & $40.37^{d)}$ \\
\hline Udhayam (GHCL Ltd., & Minimum $30 \mathrm{ppm}$ of iodine & 40.19 & 39.62 & 41.60 & 39.66 \\
\hline \multirow[t]{3}{*}{ Thirupporor, Tamilnadu, India) } & $\equiv$ iodate $41.34 \mathrm{ppm}$ & 39.04 & 39.62 & 40.00 & 38.60 \\
\hline & & 39.91 & 40.19 & 40.00 & 40.72 \\
\hline & & $39.71^{d)}$ & $39.81^{d)}$ & $40.53^{d)}$ & $39.66^{d)}$ \\
\hline Tata iodized salt (Tata Chemicals & Greater than $15 \mathrm{ppm}$ of iodine & 41.05 & 41.34 & 40.00 & 40.77 \\
\hline \multirow[t]{3}{*}{ Ltd., Mumbai, India) } & $\equiv$ iodate greater than $20.67 \mathrm{ppm}$ & 40.19 & 40.48 & 38.40 & 40.72 \\
\hline & & 40.77 & 40.19 & 40.00 & 39.66 \\
\hline & & $40.67^{d)}$ & $40.67^{d)}$ & $39.47^{d)}$ & $40.72^{d)}$ \\
\hline i-shakti crystal (Tata Chemicals & Greater than $15 \mathrm{ppm}$ of iodine & 40.19 & 40.19 & 41.60 & 42.30 \\
\hline \multirow[t]{3}{*}{ Ltd., Mumbai, India) } & $\equiv$ iodate greater than $20.67 \mathrm{ppm}$ & 39.62 & 40.19 & 38.40 & 40.72 \\
\hline & & 40.38 & 40.19 & 40.00 & 40.72 \\
\hline & & $40.07^{d)}$ & $40.19^{d)}$ & $40.00^{d)}$ & $41.25^{d)}$ \\
\hline
\end{tabular}

a) $1 \mathrm{~g}$ of the salt sample dissolved in $25 \mathrm{ml}$ of water was subjected to reduction by $\mathrm{Zn} / \mathrm{H}^{+}$or $\mathrm{NH}_{2} \mathrm{NH}_{2} / \mathrm{H}^{+}$. Volume was made upto $50 \mathrm{ml} .3 \mathrm{ml}$ of this solution was used for the analyses by the proposed method. b) Volume of salt sample used: $10 \mathrm{ml}$ of $25 \%$ salt solution. c) $20 \mathrm{~g}$ of the salt sample was dissolved in $100 \mathrm{ml}$. To this solution $10 \mathrm{ml}$ of $10 \%$ $\mathrm{KI}$ and $5 \mathrm{ml}$ of $2 \mathrm{~N}$ sulphuric acid were added. The contents were titrated against $0.05 \mathrm{~N}$ sodium thiosulphate solution using starch as indicator. $d$ ) Average of three determinations.

Table 2A. Determination of Iodate in Iodized Salt

\begin{tabular}{|c|c|c|c|c|c|}
\hline \multirow[t]{2}{*}{ Salt sample (Manufacturer) } & \multirow[t]{2}{*}{ Manufacturer's claim } & \multicolumn{2}{|c|}{$\begin{array}{c}\text { Amount of iodate } \\
\text { present }(\mathrm{ppm}) \\
\text { Developed method }^{a)}\end{array}$} & \multirow{2}{*}{$\begin{array}{l}\text { Amount of iodate } \\
\text { present (ppm) } \\
p \text {-Phenylene } \\
\text { diamine } \\
\text { method }^{b)}\end{array}$} & \multirow{2}{*}{$\begin{array}{l}\text { Amount of iodate } \\
\text { present }(\mathrm{ppm}) \\
\text { BIS method }{ }^{c)}\end{array}$} \\
\hline & & $\mathrm{Zn} / \mathrm{H}^{+}$ & $\mathrm{NH}_{2} \mathrm{NH}_{2} / \mathrm{H}^{+}$ & & \\
\hline \multirow{5}{*}{$\begin{array}{l}\text { Marken Jodsalz }^{d)} \text { Reines } \\
\text { Alpensalz aus Natursole+Fluorid+ } \\
\text { Folsaure (Sudsalz Gmbh, Ridlerstr. } \\
75,80339 \text { Munchen) }\end{array}$} & Iodate $20.4 \mu \mathrm{g}$ & 21.19 & 21.19 & 21.67 & 21.86 \\
\hline & & 21.01 & 21.19 & 21.67 & 20.40 \\
\hline & & 21.01 & 21.01 & 22.50 & 21.86 \\
\hline & & $21.07^{f)}$ & $21.13^{f)}$ & $21.95^{f)}$ & $21.37^{f)}$ \\
\hline & $\equiv$ potassium iodate $0.0025 \%$ & $0.00257 \%$ & $0.00258 \%$ & $0.00268 \%$ & $0.00261 \%$ \\
\hline \multirow{5}{*}{$\begin{array}{l}\text { Altlander }{ }^{e)} \text { Jodsalz mit Fluor } \\
\text { (Akzo Nobel Salt bv, } \\
\text { Den Niederlanden) }\end{array}$} & Iodate $20.4-32.5 \mu \mathrm{g}$ & 21.70 & 21.70 & 20.83 & 21.87 \\
\hline & & 21.53 & 21.53 & 20.00 & 21.13 \\
\hline & & 21.53 & 21.53 & 20.00 & 20.40 \\
\hline & & $21.59^{f)}$ & $21.59^{f}$ & $20.28^{f)}$ & $21.13^{f)}$ \\
\hline & $\equiv$ potassium iodate $0.0025-0.0042 \%$ & $0.00264 \%$ & $0.00264 \%$ & $0.00248 \%$ & $0.00258 \%$ \\
\hline
\end{tabular}

a) $2.5 \mathrm{~g}$ of the salt sample dissolved in $25 \mathrm{ml}$ of water was subjected to reduction by $\mathrm{Zn} / \mathrm{H}^{+}$or $\mathrm{NH}_{2} \mathrm{NH}_{2} / \mathrm{H}^{+}$. Volume was made upto $50 \mathrm{ml}$. $3 \mathrm{ml}$ of this solution was used for the analyses by the proposed method. b) Volume of salt sample used: $16 \mathrm{ml}$ of a $30 \%$ salt solution. c) $20 \mathrm{~g}$ of the salt sample was dissolved in $100 \mathrm{ml}$. To this solution $10 \mathrm{ml}$ of $10 \% \mathrm{KI}$ and $5 \mathrm{ml}$ of $2 \mathrm{~N}$ sulphuric acid were added. The contents were titrated against $0.05 \mathrm{~N}$ sodium thiosulphate solution using starch as indicator. $d$ ) Marken Jodsalz contain ingredients such as calcium carbonate, magnesium carbonate, sodium fluoride $0.047-0.064 \%$ as additives in addition to iodate. e) Altander Jodsalz contain ingredients such as potassium fluoride $0.065-0.087 \%$, sodium hexacyanoferrate(II)[E535] and silicon dioxide[E551] as additives in addition to iodate. $f$ ) Average of three determinations.

sulphuric acid were added. The contents were mixed well and the volume made upto $25 \mathrm{ml}$ with water. The colour developed was measured at $525 \mathrm{~nm}$. A calibration graph was obtained by plotting absorbance versus amount of iodate. Salt samples were analysed by the $p$-phenylenediamine (ppda) method by taking $10 \mathrm{ml}$ of $25 \%$ salt solution, $6 \mathrm{ml}$ of water, $4 \mathrm{ml}$ of $0.5 \%$ ppda solution in sulphuric acid in a $25 \mathrm{ml}$ calibrated flask. The contents were mixed well and the volume was made upto $25 \mathrm{ml}$. The colour developed was measured at $525 \mathrm{~nm}$. The amount of iodate present in the salt sample was established from the calibration graph. Samples containing iodide or iodine were converted to iodate using bromine water and removing excess bromine with formic acid. ${ }^{27)}$ The formed iodate was determined by $p$-phenylenediamine (ppda) method.

Table 3 shows the results obtained for the analysis of iodide in iodized salt from U.K. and U.S.A. There is a good agreement between the results obtained by the proposed and reference method. ${ }^{2}$ Iodophore is a weak complex of iodine and carrier polymer. It has a prolonged microbial action and used as an antiseptic and disinfectant. It is mainly used for cleaning the contaminated wounds, preoperative skin and 
disinfection of equipments. Pharmaceutical preparations containing iodine were purchased from the local market and analyzed for iodine content by the proposed and $p$-phenylenediamine (ppda) method. Table 4 shows the results obtained for the analysis of iodine in pharmaceutical preparations.

1. Determination of Iodate in Iodized Salt: a) Salt samples containing iodate from the local market and Germany were analysed by $\mathrm{Zn} / \mathrm{H}^{+}$and $\mathrm{NH}_{2} \mathrm{NH}_{2} / \mathrm{H}^{+}$reduction methods. Salt samples were dissolved in water and made up to known volume. Salt solutions containing insoluble additives such as magnesium carbonate, calcium carbonate and silicon dioxide

Table 3. Determination of Iodide in Iodized Salt

\begin{tabular}{|c|c|c|c|}
\hline $\begin{array}{c}\text { Salt sample } \\
\text { (Manufacturer) }\end{array}$ & $\begin{array}{l}\text { Manufacturer's } \\
\text { claim }\end{array}$ & $\begin{array}{l}\text { Amount of } \\
\text { iodide present } \\
(\mu \mathrm{g}) / \mathrm{g} \\
\text { Developed } \\
\text { method }^{a}\end{array}$ & $\begin{array}{c}\text { Amount of } \\
\text { iodide present }(\mu \mathrm{g}) / \mathrm{g} \\
p \text {-Phenylene } \\
\text { diamine } \\
\text { method }^{b)}\end{array}$ \\
\hline $\begin{array}{l}\text { Cerebos Extra fine } \\
\text { iodized table } \\
\text { salt }{ }^{c)} \text { (Cerebos, } \\
\text { Middlewich, Chechire, } \\
\text { England) }\end{array}$ & $\begin{array}{l}\equiv(\text { Potassium Iodide } \\
1150 \mu \mathrm{g} / 100 \mathrm{~g})\end{array}$ & $\begin{array}{c}8.375 \\
8.625 \\
8.500 \\
8.500^{e)} \\
\\
(1111 \mu \mathrm{g} / 100 \mathrm{~g})^{e)}\end{array}$ & $\begin{array}{c}8.063 \\
8.868 \\
8.868 \\
8.600^{e)} \\
(1127 \mu \mathrm{g} / 100 \mathrm{~g})^{e)}\end{array}$ \\
\hline $\begin{array}{l}\text { Diamond Crystal } \\
\text { iodized salt }{ }^{d)} \\
\text { (Cargill Incorporaed, } \\
\text { Minneapolis, } \\
\text { MN-55440) }\end{array}$ & $\begin{array}{l}\equiv(\text { Potassium Iodide } \\
0.0064 \%)\end{array}$ & $\begin{array}{l}49.000 \\
51.001 \\
48.500 \\
49.500^{e)} \\
\\
(0.00649 \%)^{e)}\end{array}$ & $\begin{array}{l}49.930 \\
48.770 \\
49.930 \\
49.540^{e)} \\
\\
(0.00649 \%)^{e)}\end{array}$ \\
\hline
\end{tabular}

a) Volume of sample used: Cerebos salt, $2 \mathrm{ml}$ of $10 \%$ salt solution; Diamond Crystal salt, $1 \mathrm{ml}$ of $5 \%$ salt solution. b) Volume of sample used: Cerebos salt, $12 \mathrm{ml}$ of $30 \%$ salt solution; Diamond Crystal salt, $10 \mathrm{ml}$ of $25 \%$ salt solution. c) Cerebos Iodized salt contain ingredients such as magnesium carbonate, sodium hexacyanoferrate(II) as anticaking agents in addition to iodide. $d$ ) Diamond Crystal iodizd salt contain ingredients such as silicon dioxide, tricalcium phosphate, dextrose and sodium bicarbonate as additives in addition to iodide. e) Average of three determinations. were filtered before diluting to known volume. One gram of salt sample from local market and $2.5 \mathrm{~g}$ of salt sample from Germany were used for the reduction of iodate to iodide with $\mathrm{Zn} / \mathrm{H}^{+}$or $\mathrm{NH}_{2} \mathrm{NH}_{2} / \mathrm{H}^{+}$. A $3 \mathrm{ml}$ aliquot containing not more than $3.5 \mu \mathrm{g}$ of iodide was used for the analysis by the proposed method. The results were also compared with the reference method ${ }^{2)}$ and BIS (Bureau of Indian Standards-IS 7224: 1985 ) method. $^{28)}$ In the BIS method, $20 \mathrm{~g}$ of salt sample was dissolved in $100 \mathrm{ml}$ of water, to this $10 \mathrm{ml}$ of $10 \%$ potassium iodide solution and $5 \mathrm{ml}$ of $2 \mathrm{~N}$ sulphuric acid were added. The liberated iodine was titrated against $0.05 \mathrm{~N}$ sodium thiosulphate solution, adding $1 \mathrm{ml}$ of $1 \%$ starch solution near the end of titration. The results are summarized in Tables 2 and $2 \mathrm{~A}$.

b) Salt samples containing iodide one each from U.K. and U.S.A. was analyzed. Ten grams of the salt sample (Cerebos Extra fine iodized salt from U.K.) and $5 \mathrm{~g}$ of the salt sample (Diamond Crystal iodized salt from U.S.A.) were dissolved in $100 \mathrm{ml}$ of water. Suitable aliquot of the salt solution containing not more than $3.5 \mu \mathrm{g}$ was used to determine the amount of iodide by the proposed method. The results (Table 3 ) were compared with the $p$-phenylenediamine (ppda) method after oxidation of iodide to iodate with $2 \mathrm{ml}$ of $300 \mathrm{ppm}$ bromine solution. The excess bromine was destroyed by the addition of $1 \mathrm{ml}$ of $85 \%$ formic acid.

2. Determination of Iodine in Pharmaceutical Preparations: a) Wokadine ointment: About $0.5 \mathrm{~g}$ of the Wokadine ointment was dissolved in $50 \mathrm{ml}$ of water. One milliliter of this solution was diluted to $50 \mathrm{ml}$. A suitable aliquot containing not more than $3.5 \mu \mathrm{g}$ of iodine was withdrawn from this solution and analyzed to determine the amount of iodine by the proposed method. The results were compared with the $p$ phenylenediamine (ppda) method after oxidation of iodine to iodate with $2 \mathrm{ml}$ of $300 \mathrm{ppm}$ bromine solution. The excess bromine was destroyed by the addition of $1 \mathrm{ml}$ of $85 \%$ formic acid. The results are shown in Table 4.

Table 4. Determination of Iodine in Pharmaceuticals

\begin{tabular}{|c|c|c|c|c|c|}
\hline \multirow[b]{2}{*}{ Sample (Manufacturer) } & \multirow[b]{2}{*}{ Manufacturer's claim } & \multicolumn{2}{|c|}{ Developed method ${ }^{a)}$} & \multicolumn{2}{|c|}{$p$-Phenylenediamine method ${ }^{b)}$} \\
\hline & & $\begin{array}{l}\text { Concentration } \\
\text { of iodine in } \\
\text { sample }(\mu \mathrm{g})\end{array}$ & $\begin{array}{l}\% \text { of iodine in } \\
\text { sample }\end{array}$ & $\begin{array}{l}\text { Concentration of } \\
\text { iodine in } \\
\text { sample }(\mu \mathrm{g})\end{array}$ & $\begin{array}{l}\% \text { of iodine in } \\
\text { sample }\end{array}$ \\
\hline Wokadine ointment & Available iodine & 2.975 & 0.496 & 98.694 & 0.494 \\
\hline (Wockhardt Ltd., & $0.5 \% \mathrm{w} / \mathrm{w}$ & 2.950 & 0.492 & 101.597 & 0.508 \\
\hline New Delhi, India) & & 3.000 & $\begin{array}{l}0.500 \\
0.496^{c)}\end{array}$ & 98.694 & $\begin{array}{l}0.494 \\
0.498^{c)}\end{array}$ \\
\hline Betadine solution (G.S. & Available iodine & 2.975 & 0.494 & 101.597 & 0.508 \\
\hline Pharmbutor Pvt. Ltd., & $0.5 \% \mathrm{w} / \mathrm{v}$ & 2.975 & 0.496 & 101.597 & 0.508 \\
\hline Uttarakhand, India) & & 2.950 & $\begin{array}{l}0.492 \\
0.494^{c)}\end{array}$ & 98.694 & $\begin{array}{l}0.494 \\
0.503^{c)}\end{array}$ \\
\hline Betadine ointment (G.S. & Available iodine & 2.950 & 0.492 & 98.694 & 0.494 \\
\hline Pharmbutor Pvt. Ltd., & $0.5 \% \mathrm{w} / \mathrm{w}$ & 2.950 & 0.492 & 101.597 & 0.508 \\
\hline Rajasthan, India) & & 2.975 & $\begin{array}{l}0.496 \\
0.493^{c)}\end{array}$ & 98.694 & $\begin{array}{l}0.494 \\
0.498^{c)}\end{array}$ \\
\hline Collosol iodine & Available iodine & 2.425 & $8.082 \mathrm{mg} / 5 \mathrm{ml}$ & 98.694 & $8.225 \mathrm{mg} / 5 \mathrm{ml}$ \\
\hline oral solution (Solvay & $8 \mathrm{mg} / 5 \mathrm{ml}$ & 2.475 & $8.250 \mathrm{mg} / 5 \mathrm{ml}$ & 95.791 & $7.983 \mathrm{mg} / 5 \mathrm{ml}$ \\
\hline $\begin{array}{l}\text { Pharma India Limited, } \\
\text { Ahmedabad, India) }\end{array}$ & & 2.475 & $\begin{array}{l}8.250 \mathrm{mg} / 5 \mathrm{ml} \\
8.195 \mathrm{mg} / 5 \mathrm{ml}^{c)}\end{array}$ & 95.791 & $\begin{array}{l}7.983 \mathrm{mg} / 5 \mathrm{ml} \\
8.063 \mathrm{mg} / 5 \mathrm{ml}^{c)}\end{array}$ \\
\hline
\end{tabular}

a) Wokadine and Betadine ointment ( $0.5 \mathrm{~g}$ of ointment dissolved in $50 \mathrm{ml}$ water, $1 \mathrm{ml}$ of this solution was diluted to $50 \mathrm{ml}, 3 \mathrm{ml}$ of this solution was used), Betadine solution $(0.5 \mathrm{ml}$ dissolved in $50 \mathrm{ml}, 1 \mathrm{ml}$ of this solution diluted to $50 \mathrm{ml}, 3 \mathrm{ml}$ of this solution was used.), Collosol iodine oral solution ( $2.5 \mathrm{ml}$ dissolved in $100 \mathrm{ml}$ of water, $1 \mathrm{ml}$ of this solution was diluted to $50 \mathrm{ml}, 3 \mathrm{ml}$ of this solution was used.) b) Wokadine and Betadine ointment ( $0.5 \mathrm{~g}$ of ointment dissolved in $250 \mathrm{ml}$ water, $10 \mathrm{ml}$ of this solution was used), Betadine solution ( $1 \mathrm{ml}$ dissolved in $250 \mathrm{ml}$ water, $5 \mathrm{ml}$ of this solution was used), Collosol iodine oral solution ( $2.5 \mathrm{ml}$ dissolved in $250 \mathrm{ml}$ of water, $6 \mathrm{ml}$ of this solution was used). c) Average of three determinations. 
b) Betadine ointment: About $0.5 \mathrm{~g}$ of the Betadine ointment was dissolved in $50 \mathrm{ml}$ of water. One milliliter of this solution was diluted to $50 \mathrm{ml}$. A suitable aliquot containing not more than $3.5 \mu \mathrm{g}$ of iodine was withdrawn from this solution and analyzed to determine the amount of iodine by the proposed method. The results were compared with the $p$ phenylenediamine (ppda) method after oxidation of iodine to iodate with $2 \mathrm{ml}$ of $300 \mathrm{ppm}$ bromine solution. The excess bromine was destroyed by the addition of $1 \mathrm{ml}$ of $85 \%$ formic acid. The results are tabulated in Table 4.

c) Betadine solution: One milliliter of Betadine solution was diluted with $50 \mathrm{ml}$ of water. One milliliter of this solution was diluted to $50 \mathrm{ml}$. A suitable aliquot of iodine containing not more than $3.5 \mu \mathrm{g}$ was withdrawn from this solution and analyzed to determine iodine by the proposed method. The results were compared with the $p$-phenylenediamine (ppda) method after oxidation of iodine to iodate with $2 \mathrm{ml}$ of $300 \mathrm{ppm}$ bromine solution. The excess bromine was destroyed by the addition of $1 \mathrm{ml}$ of $85 \%$ formic acid. The results are shown in Table 4.

d) Collosol: Collosol solution $2.5 \mathrm{ml}$ was diluted with $100 \mathrm{ml}$ of water. One milliliter of this solution was diluted to $50 \mathrm{ml}$. A suitable aliquot containing not more than $3.5 \mu \mathrm{g}$ of iodine was withdrawn from this solution and analyzed to determine iodine by the proposed method. The results were compared with the $p$-phenylenediamine (ppda) method after oxidation of iodine to iodate with $2 \mathrm{ml}$ of $300 \mathrm{ppm}$ bromine solution. The excess bromine was destroyed by the addition of $1 \mathrm{ml}$ of $85 \%$ formic acid. The results are shown in Table 4 .

\section{Conclusion}

The developed method is simple, precise and sensitive for the determination of iodine species like iodide, iodine, iodate or periodate. The system obeys Beer's law in the concentration range of $0-3.5 \mu \mathrm{g}$ of iodide in an overall volume of $10 \mathrm{ml}$ with the molar absorptivity of $1.73 \times 10^{5} 1 \mathrm{~mol}^{-1} \mathrm{~cm}^{-1}$. The developed method is more sensitive compared to the spectrophotometric methods based on the oxidation of leuco xylene cyanol $\mathrm{FF}^{14)}\left(\varepsilon=1.7 \times 10^{4} 1 \mathrm{~mol}^{-1} \mathrm{~cm}^{-1}\right)$ and thionin $^{15)}\left(\varepsilon=2.7 \times 10^{4} 1 \mathrm{~mol}^{-1} \mathrm{~cm}^{-1}\right)$ with iodate. The molar absorptivity of the developed method is comparable to the extraction method based on the ion pair with brilliant green ${ }^{13)}\left(\varepsilon=3.0 \times 10^{5} 1 \mathrm{~mol}^{-1} \mathrm{~cm}^{-1}\right)$ or methylene blue ${ }^{12)}$ $\left(\varepsilon=3.1 \times 10^{4} 1 \mathrm{~mol}^{-1} \mathrm{~cm}^{-1}\right)$. The application of proposed method to the determination of iodide and iodate in salt sam- ples and iodine in pharmaceutical preparations demonstrate the utility of the method to serve as alternate to the existing methods.

Acknowledgement One of the authors (MG) sincerely acknowledges the encouragement and support from Dr. Sr. Annamma Philip, Principal, Stella Maris College, Chennai, UGC (New Delhi) and DCE (TamilNadu Government) for the leave granted on FIP scheme for the Doctoral programme.

\section{References}

1) Gilman A. G., Goodman L. S., Rad T. S., Murad F., "The Pharmacological Basis of Therapeutics," 7th ed., Macmillan, New York, 1985, p. 964

2) Trivedi R. H., Mehta S. H., Bhatt S. D., Choudhri B. P., Indian J. Technol., 25, 43 (1987).

3) Alegret S., Florido A., Lima J. L. F. C., Machado A. A. S. C., Talanta, 8, 825-829 (1989).

4) Crecelins E. A., Anal. Chem., 47, 2034-2037 (1975).

5) Vanhoe H., van Allemeersch F., Versieck J., Dams R., Analyst, 118, 1015-1019 (1993).

6) Schrame P., Hasse S., Microchim. Acta, 116, 205-209 (1994).

7) Rubio S., Perez-Bendito D., Anal. Chim. Acta, 224, 185-198 (1989).

8) Kennedy R. O., Bator J., Reading C., Anal. Biochem., 179, 139 (1989).

9) Garcia M. S., Sanchez-Pedreno C., Albero M. I., Sanchez C., Analyst, 116, 653 - 656 (1991).

10) Yonehava N., Yamana T., Tomiyasu T., Sakamoto H., Anal. Sci., 5, 175-180 (1989)

11) Esmadi F. T., Kharoaf M. A., Attiyat M. S., Analyst, 116, 353-357 (1991).

12) Koh T., Ono M., Makino I., Analyst, 113, 945-948 (1989).

13) Niazi S. B., Mozammil M., Anal. Chim. Acta, 252, 115-119 (1991).

14) Chand Pasha, Narayana B., Acta Chim. Slov., 53, 77-80 (2006)

15) Narayana B., Cherian T., J. Braz. Chem. Soc., 16, (2005)

16) Bhattacharyya S. N., Chetia P. K., Anal. Chem., 19, 369-370 (1967).

17) Kamburova M., Talanta, 39, 997-1000 (1992).

18) El-Shahawi M. S., Al-Hashimi F. A., Talanta, 43, 2037-2043 (1996).

19) Harez A., Bashir W., Microchem. J., 31, 375-379 (1985).

20) Callejon M., Munoz J., Microchem. J., 34, 83-88 (1986).

21) El-Shahawi M. S., Anal. Chim. Acta, 356, 85-91 (1997).

22) Cason D. L., Neumann H. M., J. Am. Chem. Soc., 83, 1819-1822 (1961).

23) Laitinen H. A., Boyer K. W., Anal. Chem., 44, 920-926 (1972).

24) March J., "Organic Chemistry Reaction Mechanism and Structure," 3rd ed., Wiley Publication, New Delhi, 1986, p. 478.

25) Balasubramanian N., Usha S., Srividhya K., Indian Drugs, 32, 78-83 (1995).

26) Gayathri N., Balasubramanian N., J. AOAC Int., 84, 1065-1069 (2001).

27) Bhatty M. K., Townshend A., Anal. Chim. Acta, 56, 55-60 (1971).

28) Indian Standard Specification for Iodized Salt IS 7224: Bureau of Indian Standards, New Delhi, 1985, pp. 986, 987. 